\title{
Trauma and Escapism: The Dual Faces of Holocaust in Markus
}

\section{Zusak's The Book Thief}

\section{Nicky Victor}

PG \& Research Dept of English

Fatima Mata National College (Autonomous)

Kollam, Kerala, India

Dr. Cynthia Catherine Michael

Assoc Prof \& Head

PG \& Research Dept of English

Fatima Mata National College (Autonomous)

Kollam, Kerala.

cynthiamichae12006@yahoo.com

\begin{abstract}
Markus Zusak's novel, The Book Thief wholly recaptures the trauma induced by war-torn Germany upon its inhabitants. This study serves the purpose of juxtaposing the traumatic bereavement of the Holocaust survivors with their various escaping tendencies. The chief protagonist of the novel, Liesel is representative of the entire traumatized community who faces the darkest moments of their life and still survives. Her story as part of the developing canon of Holocaust literature thus exposes the destructive trauma and affirms the importance of community in the rehabilitation of the traumatized. The power of words as an escaping force amidst all the upheaval provided much impetus to the distressed souls of Nazi Germany. Books emerged as an escaping force in the lives of many in times of all treachery
\end{abstract}


and destitute. Trauma and escapism hence, binds together the traumatic experiences and the escaping strategies which the characters share among themselves under a dictatorial setup.

Keywords: Trauma, Books, Holocaust, Victim, Escapism.

Trauma and Escapism serve as the dual faces of Holocaust literature. In The Book Thief the unnerving traumas of the characters are interspersed along with their various escaping tendencies in order to fully capture the soberness of that particular period in history. Trauma is an important aspect of the Holocaust, used to refer both to the negative events that produce distress and to the distress itself. In Beyond the Pleasure Principle (1994), Freud defined traumatic neurosis as "a consequence of an extensive breach being made in the protective shield against stimuli (303)”. Michael Rothberg, in Traumatic Realism (1992), discusses the present concern with contemporary trauma in the light of the Holocaust as, "exploring the recent fascination with the Holocaust means exploring a more general contemporary fascination with trauma, catastrophe, the fragility of memory, and the persistence of ethnic identity" (Rothberg 10). Markus Zusak's novel, The Book Thief is completely overshadowed by the various traumatic undertones ignited by the Holocaust and the Second World War. The traumatic concepts in the novel are depicted with an emphasis on the changing discourse between the victim and the perpetrator, as it attempts to confront the effects of both Holocaust memory and the German perpetrator trauma.

Markus Zusak is a young adult fictionist of German-Austrian descent renowned for his artistic craftsmanship and exuberance. His literary output which spans over six major novels, are the ultimate exemplars of his literary genius. The Underdog, Zusak's first novel published in 1999 is followed by its two sequels Fighting Ruben Wolfe (2001) and When Dogs Cry (2002). This was followed by his two major masterpieces The Messenger (2002) and The Book Thief (2005), and his most recent publication Bridge of Clay (2018), which won the writer much critical acclaim and recognition. Zusak's magnum opusThe Book Thief 
published in 2005 is a true rendition of all that is unsettling, thought-provoking, lifeaffirming, triumphant and tragic in nature, and is a one that could be a wonderful page-turner in the history of young adult fiction.

The Book Thief offers a realistic portrayal of the Holocaust from a removed yet effective perspective, shedding light on the horrors associated with one of the darkest chapters in the face of world history. Zusak's novel is truly an eye-opener to its readers on the atrocious horrors of the Holocaust and the inextinguishable hope of humanity beneficial in representing and imagining the Holocaust. Juxtaposing the innocence of children with the atrocities of the Nazi regime serves to emphasize the horrors of the Holocaust even more clearly in the novel. Hence,the child protagonist of the novel, Liesel Meminger bears a living testimony to the intensity of destruction that the Second World War can have upon the life of a fragile being like a child.

Zusak exaggerated the traumatic bereavement of Liesel Meminger, the nine-year old protagonist of the novel with utmost care and concern. Liesel's story represents the universal experience of those involved in the Holocaust, whether they are victims, observers or oppressors. Her trauma thus becomes the trauma of the entire generation of her sympathizers. Liesel's traumatic experiences in life begin and end within Death's palm — both the tragic death of her brother and the cataclysmic destruction of Himmel Street that concludes it. These encounters plunge her into a journey of traumatic proportions as she searches for grounding in the constant upheaval. Although Liesel at times feel that the reason for her real trauma is her war against Hitler, the actual battle rages between her self-understanding and acceptance of death.

The initial disastrous blow came upon Liesel in the form of the death of her only brother, Werner, who was a portion of her life. The heaviness of this tragedy stood unbearable for a young girl of her age, hence she appeared completely struck, unable to 
recognize the quality of the trauma to which she is subjugated. Her senses too appeared frozen along with her tears, struggling to let off her encumbering emotions: "For Liesel Meminger, there was the imprisoned stiffness of movement, and the staggered onslaught of thoughts. Esstimmtnicht. This isn't happening and the shaking(21)". Once it promulgated out of her, it seemed just like a massive ocean of untamed waves. The instant crest and trough of her engorging emotions resulted in Liesel's misplacement of her real self: "Still in disbelief, she started to dig. He couldn't be dead . . . snow carved into her skin . . . she could see her broken heart, in two pieces. Each half was glowing, and beating under all that white (24)". Her heart broke apart at the sight of the death of her only sole companion in life.

While her little brother's death is enough to send Liesel down a traumatic spiral, her trauma builds when her mother abandons her. She constantly endures visions of her mother, seeing her face "a hundred times in a single afternoon (38)". Her trauma further intensified when she recognized "Kommunisten" to be a taboo word like the Jews. Her small heart beat so violently on thinking about the fate of her mother; she feared that her mother would also be traumatized like the Jews.

The trauma caused by war scattered immense losses in the life of Liesel. The most notable of them were the departure of her foster parents, Hans and Rosa Hubermann and of Rudy Steiner, her best friend. Among them all, Hans Hubermann's loss inflicted great pain within Liesel's heart. Hans was not just a foster father to Liesel; he was the very music of her soul, with his accordion and his pair of silver eyes. His death left the greatest void in the life of Liesel, her final words of departure to her "papa", her most beloved soul is as follows: “"Goodbye, Papa, you saved me. You taught me to read' ... Her arms held him. She kissed his shoulder — she couldn't bear to look at his face any more — and she placed him down again(573)". Liesel's reaction at witnessing the lifeless body of Rudy Steiner was also not much different. She felt that her eyes had betrayed her soul, her bemoaning filled the dusty 
skies, “'Rudy', she sobbed, 'wake up ... 'She grabbed him by his shirt and gave him just the slightest, disbelieving shake . . . 'Rudy, please'. The tears grappled with her face (570)". Thus, Liesel Meminger was the most pathetic survivor of the destruction caused by the Second World War. The path she had treaded so far becomes the ultimate exemplar of childhood trauma and of its negative implicature.

Max Vandenburg, the Jewish fist-fighter was a victim of the war and of the Holocaust. When Max arrives on Himmel Street for the first time, he carries the fear of a German Jew and the guilt of a survivor upon his shoulders. The chief threshold of all Max's misery was his lineage as a Jew. Jews were the main victims of the Holocaust, and were hence, addressed using all the derogatory terms like: "Jewish Filth(196)", "Jewish Stench" and as "Jewish Chum (273)". The label of a Jew remained a blot in Max's otherwise pure life; he was burdened by the feeling of being born to such a vulnerable community: "He explained that he was a Jew in upbringing, in blood, but also that Jewry was now more than ever a label - a ruinous piece of the dumbest luck around(235)".

Hans Hubermann, the accorditionist and the silver-eyed foster father of Liesel Meminger was a generous soul and a submissive person by nature. He was not an ardent supporter of the Nazi regime and has even failed to comply with their propaganda. He was often mistaken and hence traumatized for such a stand of his. There was a harsh downpour of criticisms from all sides, even from his son.

Hubermann's dilemma at failing to oblige with the Nazi faction arouse from a valid personal reason of his:

A Jew had once saved his life and he couldn't forget that. He couldn't join a party that antagonized people in such a way. Also ... some of his most loyal customers were Jewish. Like many of the Jews believed, he didn't think the 
hatred could last, and it was a conscious decision not to follow Hitler. (194-

His life was the result of a great sacrifice made by a Jew, for which he is much indebted to and which prevents him from signing up with the Führer. Hans' act of empathy towards a Jewish prisoner turned to be another pitfall in his life. This single deed of him attracted much ire from all around, and hence he was condemned to be a "Jew Lover" by the world. Thus, in a way Hubermann's trauma was self-made, where his deeds of sympathy turned to be the villains in his life.

Escapism is another of the staple elements of the Holocaust literature. The term is used to describe the phenomenon of escaping reality in order to cope with the harsh realities of life. According to Robert Heilman, "the term was first used in the 1930 (439)". From then on, its popularity grew, and in the 1940s and 50s it became "a staple of all kinds of criticism (444)", such as historical and political, but also literary and artistic. Heilman defines it as a, "habitual diversion of mind to imaginative activity or entertainment as an escape from reality or routine(445)".

In the novel, The Book Thief (2005), escapism helps its characters in escaping the harsh realities of the Second World War and of the Holocaust. Thus, the character who wants to escape reality, or the "escapist", can experience some relief from their real-life trauma, and is then able to resume life as usual, but the experience of a better life can also make it more difficult to return to real-life. This is the danger that the protagonist as well as the other characters in The Book Thief face, where they practically do not want to leave their fantasy world anymore.

Liesel Meminger, the book thief of the novel is the ultimate exemplar of the advantages escapism can have upon human lives. She is a character who adapted the mechanism of stealing as a means to settle with the scores of life. She sought in books a sort 
of therapeutic power which could heal her of all the wounds, inflicted upon by the sordid reality. Her first stolen book, The Gravedigger's Handbook, relieved her of the trauma caused by the death of her only brother. Hence she recognized that, “. . . the books and the words started not just to mean something, but everything (30)".

The huge library of books of Ilsa Herman, offered Liesel an alternative escape to the imaginary world of books. "It sucked her towards it (128)", and left her astonished at the marvellous scope of the world of books. Liesel's excitement can be conveyed thus: "There were all different styles and sizes of lettering on the spines of the black, the red, the grey, the every-coloured books. It was one of the most beautiful things Liesel Meminger had ever seen(145)". Thus, the vibrantly jacketed books turned into Liesel's soul mates in times of her distress. Liesel's wild escape to the world of books can be exaggerated as follows:

She walked over and did it again, this time much more slowly, with her hand facing forward, allowing the dough of her palm to feel the small hurdle of each book. It felt like magic, like beauty, as bright lines of light shown down from a chandelier. Several times she almost pulled a title from its place but didn't dare disturb them. They were too perfect. (146)

The animate world of books thus wholly enticed the psyche of Liesel. Thus, Liesel Meminger's escapism came through her recourse to the microcosmic world of books of which she was a part: "She survived because she was sitting in a basement reading through the story of her own life, checking for mistakes (528)".

Max Vandenburg's escapism can also be traced in the same lines as that of Liesel's. Max was a Jewish fist-fighter and a pathetic victim of the Holocaust. Max's escapism resumed from the moment he was forced to leave behind his family for his safety. For Max, his escapism then came through words itself, akin to the case of Liesel. Mein Kamf, the book carrying the life story of Adolf Hitler, turned "his saviour(170)" and his life-saving book. The 
book contains a map showing the route to the street in Molching, and a key to the Hubermann house. "Of all things to save him (167)", the book that was written by the man who wanted all Jews eliminated turned Max's saviour. The title of the book also ironically refers to Max, as his very existence has been a struggle against political and religious oppression.

Max's own compositions, The Standover Man and The Word Shaker too adorn the status of two escaping forces of his life. The power of words truly become evident in these works, where Max lets off his discord and anxieties associated with the Hitler-lead Nazi party. Max’s escapism can thus be expressed: “... his rescue owed itself to some reading and writing, and a book called The Shoulder Shrug (232)". Thus, books played a major role in soothing the mental trauma of Max Vandenburg.

Max, hence fitfully mastered the skill of escapism through a series of attempts. Being a Jew by birth, his major escapism was from the Nazi surveillance. He moulded himself thus: "Max Vandenburg was in the room, noiseless and opaque. The man did not breathe. He did not move (216)". Max's another set of escape was from the clutches of Death. His narrow escapism from dying the pathetic death of a Jew can be recounted from the view point of Death:

I realized much later that I actually visited 33 Himmel Street in that period of time ... for all I saw was a man in bed. I kneeled. I readied myself to insert my hands through the blankets. Then there was a resurgence - an immense struggle against my weight. I withdrew, and with so much work ahead of me, it was nice to be fought off in that dark little room. (339-340)

Thus, Death completely surrendered before the resilience of Max to conquer it. Hence Max Vandenburg arrived as one among the few characters to have survived the war and the Holocaust. 
Hans Hubermann, the silver-eyed tall man and the only accorditionist of Himmel Street, was too fortunate to have escaped Death many a time. He was the man who inhaled music as the very life-imparting soul. The relief gained from playing his accordion in turn, guarded and prolonged his life through atrocities of this transient world. His generosity and selflessness also rescued him from all adverse circumstances. Hubermann, the sergeant-cumpainter, escaped Death twice in his lifetime. His sheer optimism turned his life-guarding principle at times of all the trials and tribulations. Hans Hubermann successfully evaded Death for the very first time during the First World War and was equally optimistic about his subsistence in the Second World War. He was fortunate enough, for his fate got diverted to another individual.

Trauma and escapism thus serve as the dual faces of Holocaust literature as reflected in Zusak's novelThe Book Thief. Trauma and escapism of all the characters of both Jewish and German blood is captured poignantly in the novel. Both catered to the need of portraying the trauma inculcated by the war, and also in delineating the various methodologies adopted to evade them. Hence, trauma and escapism become the part and parcel of the Holocaust as portrayed in The Book Thief. 


\section{References}

Freud, Sigmund. "Beyond the Pleasure Principle." The Journal of Philosophy. 22. 19 (1994): 303. JSTOR. Web. 1 Mar. 2020. <www.jstor.org>.

Rothberg, Michael. Traumatic Realism: The Demands of Holocaust Representation (1992): 10. JSTOR. Web. 25 Mar. 2020. <www.jstor.org>.

Heilman, Robert. "Escape and Escapism Varities of Literary Experience." The Sewanne Review 83.3 (1975): 439- 445. Web. 9 Mar. 2020.

Schwarz, Daniel R. Imagining the Holocaust 26.1 (2000): 23. Cambridge University Press. Web. 30 Mar. 2020. <www.cambridge.org>.

Zusak, Markus. The Book Thief. New York: Alfred A. Knopf, 2005.

---. Interview by Provo Library. Online video clip. You Tube, 20 Mar. 2011. Web. 10 Feb. 2020. <youtube.com>.

---. Interview by Sandip Roy at Tata Steel Kolkata Literary Meet (Kalam 2019). Outlook India, 22 Jan. 2019. Web. 4 Apr. 2020. <www.outlookindia.com>. 